\title{
$\mathrm{COVID-19} \mathrm{기간} \mathrm{대한췌장담도학회의} \mathrm{대면-비대면} \mathrm{학술행사에}$ 대한 만족도 설문 조사
}

${ }^{1}$ 고려대학교 의과대학 내과학교실, ${ }^{2}$ 연세대학교 의과대학 내과학교실, ${ }^{3}$ 한림대학교 의과대학 내과학교실, ${ }^{4}$ 순천향대학교 의과대학 내과학교실, ${ }^{5}$ 원광대학교 의과대학 내과학교실, ${ }^{6}$ 동국대학교 의과대학 내과학교실

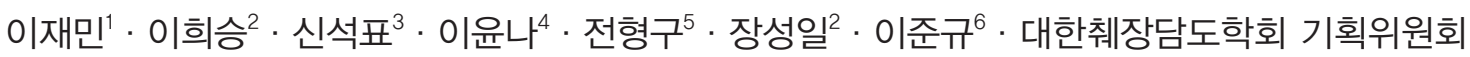

\section{A Hybrid Online and Offline International Conference of the Korean Pancreatobiliary Association in Post-COVID-19 Era}

\author{
Jae Min Lee', Hee Seung Lee ${ }^{2}$, Suk Pyo Shin ${ }^{3}$, Yun Nah Lee ${ }^{4}$, Hyung Ku Chon ${ }^{5}$, Sung III Jang ${ }^{2}$, Jun Kyu Lee ${ }^{6}$, \\ The Public Affair Board of Korean Pancreatobiliary Association \\ 'Department of Internal Medicine, Korea Universty College of Medicine, Seoul; ${ }^{2}$ Department of Internal Medicine, Yonsei University College of \\ Medicine, Seoul; ${ }^{3}$ Department of Internal Medicine, Hallym University College of Medicine, Chuncheon; ${ }^{4}$ Department of Internal Medicine, Soon \\ Chun Hyang University School of Medicine, Bucheon; ${ }^{5}$ Department of Internal Medicine, Wonkwang University School of Medicine, Iksan; \\ ${ }^{6}$ Department of Internal Medicine, Dongguk University College of Medicine, Goyang, Korea
}

Background/Aim: The COVID-19 pandemic has changed the way of traditional conference and meeting. Since social distancing rule was important issue, many conferences across the world were cancelled or postponed indefinitely. In 2020, International Conference of the Korean Pancreatobiliary Association (IC-KPBA) was held as a hybrid online and offline conference. Here, we report the result of a national survey about online and offline medical conference in Korea.

Methods: The survey was performed for both online and offline participants after IC-KPBA. The contents of survey included their way to access the hybrid online-offline conference and satisfaction with the conference format.

Results: Total of 78 participants answered the survey and there was no technical problem. Most offline participants were satisfied the prevention measures at conference hall as follows; very satisfied- $56 \%$; satisfied- $34 \%$. The quality of video and audio were generally satisfactory in both conference hall and virtual conference. 'Live online lectures' is the most preferred method of lecture delivery and personal computer with LAN network is preferred to access online conference. Eighty seven percent of offline participants and $91 \%$ of online participants answered satisfied and very satisfied, respectively.

Conclusions: Participants of IC-KPBA 2020 with hybrid online-offline conference showed a high level of satisfaction.

Korean J Pancreas Biliary Tract 2021;26(1):49-57

Keywords: COVID-19, Pandemics, Clinical conference, Feedback, Surveys and questionnaires
Received Sep. 23, 2020

Revised Dec. 4, 2020

Accepted Dec. 7,2020

Corresponding author : Jun Kyu Lee Department of Internal Medicine, Dongguk University College of Medicine, 32 Dongguk-ro, llsandong-gu, Goyang 10326, Korea

Tel: +82-31-961-7750

Fax. +82-31-961-9390

E-mail: jeromee1971@hanmail.net

ORCID: https://orcid.org/0000-0002-2694-3598

This is an Open Access article distributed under the terms of the Creative Commons Attribution Non-Commercial License (http:// creativecommons.org/licenses/by-nc/3.0/) which permits unrestricted non-commercial use, distribution, and reproduction in any medium, provided the original work is properly cited.

Copyright @ 2021 by The Korean Journal of Pancreas and Biliary Tract 


\section{서 론}

2019년에 중국에서 발생하여 알려진 중증 급성 호흡기 증후군 (severe acute respiratory syndrome coronavirus 2, SARS-CoV-2)은 COVID-19로 불리우며, ${ }^{1-3}$ 현재 전 세계로 확산되어 사회 경제 전반에 광범위한 문제를 야기하고 있다. COVID-19는 감염자와의 접촉 및 에어로졸을 통한 전파가 주 감염경로로 파악되며, 따라서 호흡기 비말의 방지 및 공공장소에서의 방역, 접촉 부위 개인 위생에 대한 관리가 강조되고 있다. ${ }^{4.5}$ 이에 대한 방역대책으로 국가마다 정도의 차이는 있으나, 국경 폐쇄, 여행 제한, 사회적 거리두기, 감염자의 격리 및 접촉자의 추적 등이 시행되고 있다. 우리나라에서는 COVID-19 확산 방지 및 예방 정책의 일환으로 공개적인 행사 및 학술 행사의 자제가 요청되고 있는 상태이다.

대한췌장담도학회는 췌장담도 질환의 최신 지견 공유와 학문적 발전, 교육 및 교류를 위해 정기적으로 학술대회를 개최하고 있으며, 국제학술행사로 International Conference of the Korean Pancreatobiliary Association (IC-KPBA)을 진행하고 있다. 하지만 COVID-19 확산에 대한 전염 방지 정책으로, 조직위원회는 2020년도 IC-KPBA를 2020년 8월 7일부터 8 일까지 2 일간 대한민국 서울에서 온라인 및 오프라인 병행 방식으로 진행하였다.

감염성 질환의 세계적인 확산으로 온라인 혹은 가상공간 에서의 행사에 대한 다양한 방법이 제시되고 있다. ${ }^{6-9}$ 이에 발맞추어 의학계를 비롯한 여러 분야에서 상당수의 학술회의가 온라인 플랫폼으로 시도되고 있다. 하지만 이러한 방식은 기존의 직접 참석의 집합형 회의와는 많은 차이가 있어 여러 시행착오와 혼선이 발견되고 있다. 대한췌장담도학회의 학술행사는 이 분야의 국내외 전문가들이 다수 참여하며 참석자의 다양성과 집단의 통일성이 있는 것이 특징이다. 본 연구에서는 IC-KPBA 2020 학술행사 참석자를 대상으로 한 설문조사 결과를 분석하였으며, COVID-19 상황에서 대안으로 제시된 비대면 학술대회의 만족도를 비교하고, 이를 통해 이상적인 방식의 학술대회를 모색하고 방안을 수립하고자 하였다.

\section{방법}

\section{1. 학술행사의 세부내용}

본 IC-KPBA 2020 학술행사는 대한췌장담도학회의 주관으로 2019년 조직위원회가 결성되었으며 초기 계획은 2020년 4월 17 일 및 18 일 2 일간 대한민국 서울에서 개최를 계획하였다. 하지만 2019년 발생한 COVID-19가 전 세계적으로 확산되어 전파의 위험 등의 사안을 감안하여 2020년 8월 7일 및 8 일로 일정을 연기하여 진행되었다. 학술행사는 실시간 시술 시연 및 초청 연자의 강연, 연구 발표로 구성되었으며, 발표자는 현장 발표를 권장하되 참석의 어려움이 있는 경우 원격 발표 혹은 녹화 발표를 하도록 하였다. 참석자는 직접 참석 혹은 온라인을 통한 원격 참여 중 선택하도록 하였으며, 온라인 참석자에게는 지정된 가상 학회장에 대한 사전 설명문을 발송 후 접속 링크 주소를 안내하였다.

행사는 국내 포함 37 개국 453 명이 등록하였으며, 현장 및 온라인 여부를 사전신청 후 확인하였다. 1 일차 참석자는 27 개국에서 현장 참석 115 명, 온라인 참석은 185 명이었으며, 2 일차는 28 개국에서 현장 참석 131 명, 온라인 참석은 188 명으로 집계되었다. 학회 프로그램은 실시간 시술 시연 2개 세션(6개 병원, 8건 시술 시연)과 학술 프로그램 연자 강연(44개 주제), 학술 연구 발표(구연 및 포스터 68편)로 구성되었으며, 세션의 축소나 취소없이 계획대로 진행되었다.

현장 참석의 경우 학회장에서 감염 방지 대책으로는 입장 시 체온 측정, 개인별 소독제 및 마스크 배포, 좌석간 $2 \mathrm{~m}$ 거리 배치, 연단의 가림막 설치가 시행되었으며 당일 접수 및 참석은 원칙적으로 금지하였다. 온라인 참석자를 위해 사전 접속 주소에 대한 공지를 이메일 및 문자 메시지를 통해 시행하였으며 사전에 인증된 코드 및 번호로 접속할 수 있도록 하였다.

\section{2. 설문의 개발과 방법}

설문은 대한췌장담도학회 기획위원회 주관 하에 진행되었으며, 학술행사의 참석자를 대상으로 발송 후 답변을 수집하였다. 설문지는 위원회에서 초안 작성 후 3 회의 회의를 거쳐 개정되었다(Appendix 1). 설문지의 주요 내용은 참석자의 인적 정보와 참석의 방법을 공통으로 하였으며, 현장 참석자의 경우 방역 대책 및 현장 방송 상태의 만족도를 조사하였다. 온라인 
참석자의 경우 온라인 참석 방식과 기기, 방송 송출 상태 및 접속 편의성 등에 대한 만족도를 조사하였다. 만족도는 총 5 개의 척도(1-매우 만족, 2-만족, 3-보통, 4-불만, 5-매우 불만)로 구성하였으며, 그 외 정보는 직접 입력 혹은 선택 항목으로 기록하도록 하였다.

설문지는 IC-KPBA 2020 종료 후 참석자를 대상으로 이메일 및 문자 발송 두 가지 방식으로 모두에게 발송하였으며, 네이버 설문조사의 플랫폼을 이용하였으며 총 4 페이지 18 개 문항으로 구성하였다(Appendix 1). 답변 작성 시간은 약 5 분 이내로 예상하였다. 설문지에 대한 회신은 총 2주 동안 수집하였으며 위원회에서 분석을 시행하였다.

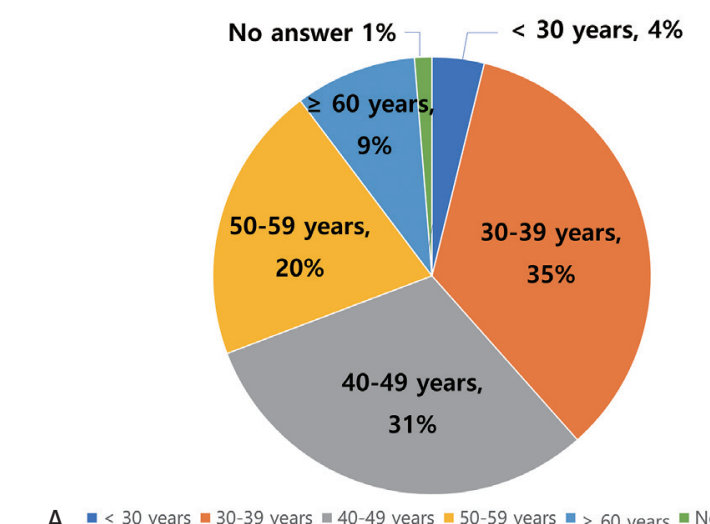

A $\square<30$ years $\| 30-39$ years $₫ 40-49$ years $\backsim 50-59$ years $\backsim \geq 60$ years $\square$ No answer

Fig. 1. Distribution of survey participants. (A) Age. (B) Gender.

\section{결 과}

본 설문조사에서 설문 참여자의 평균 연령은 $44.2 \pm 9.8$ 세 였으며, 성별은 남성이 69명, 여성이 9명이었다. 연령별 분포는 20 대 및 30 대가 $39 \%, 40$ 대가 $31 \%, 50$ 대 이상이 $29 \%$ 였으며(Fig. 1), 상급종합병원 및 종합병원 근무자가 $96 \%$ 로 대부분을 차지하였다. Fig. 2는 IC-KPBA 2020 참석 방법에 대한 결과이다. 2020년 8월 학회 개최 당시 소속의료기관의 외부 행사 참석에 대한 정책은 제한 없음이 $21 \%$, 신청 후 참석은 $31 \%$, 승인 후 참석 가능은 $17 \%$, 좌장 및 연자에 한하여 승인은 $26 \%$ 였으며, 외부 행사 참석 금지는 $6 \%$ 였다. 기존의 예정된 일정이
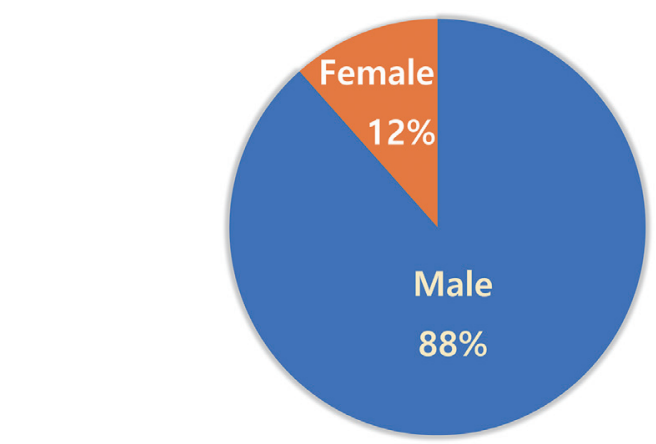

B

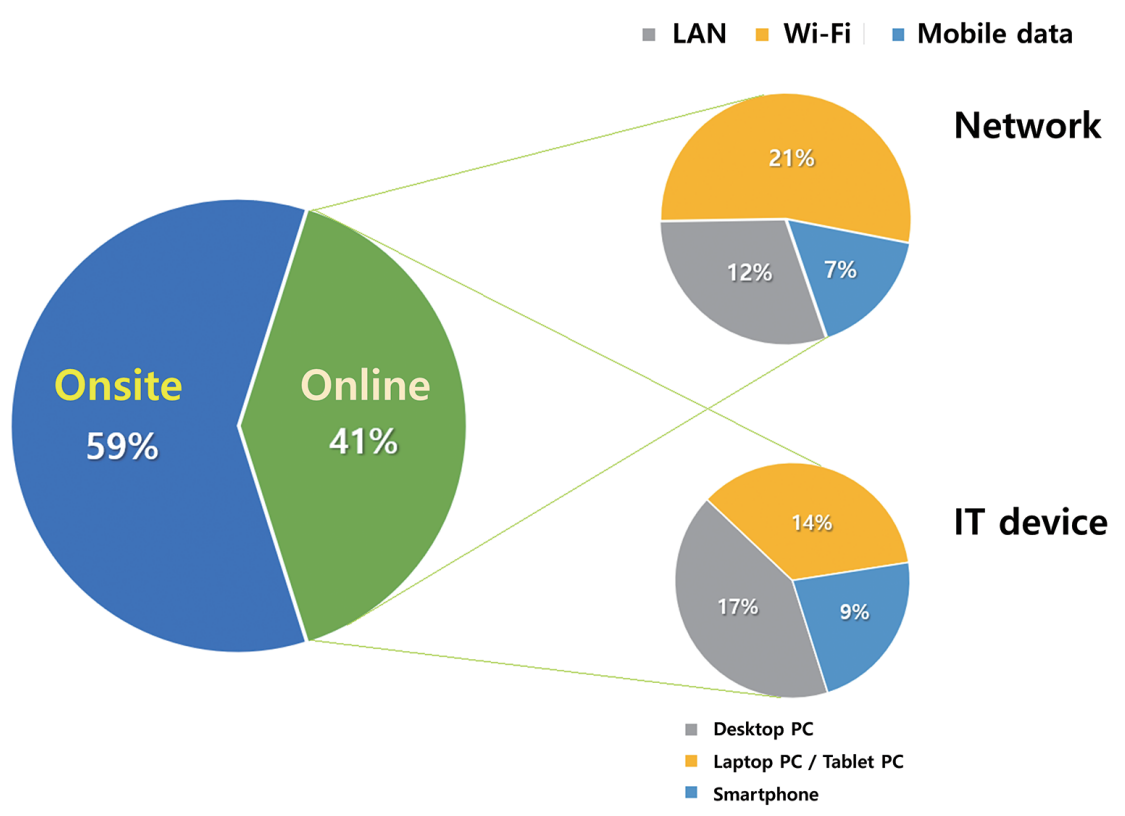

Fig. 2. Method of attending to IC-KPBA 2020. 

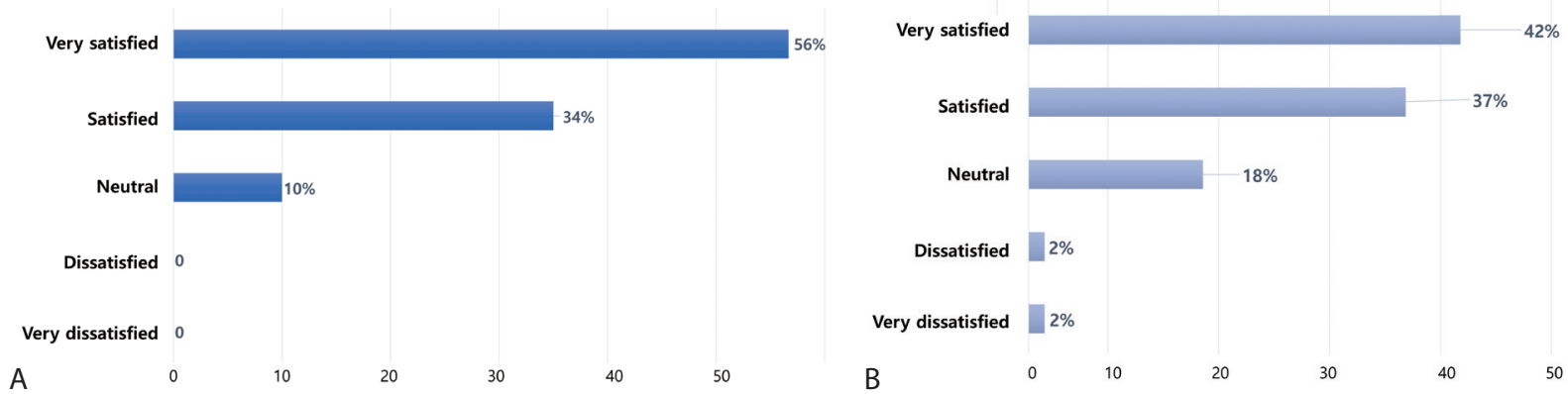

Fig. 3. Survey result from offline-attendee in IC-KPBA 2020. (A) Satisfaction level of strategies for the prevention of epidemic disease. B) Satisfaction level about the quality of video and sound.

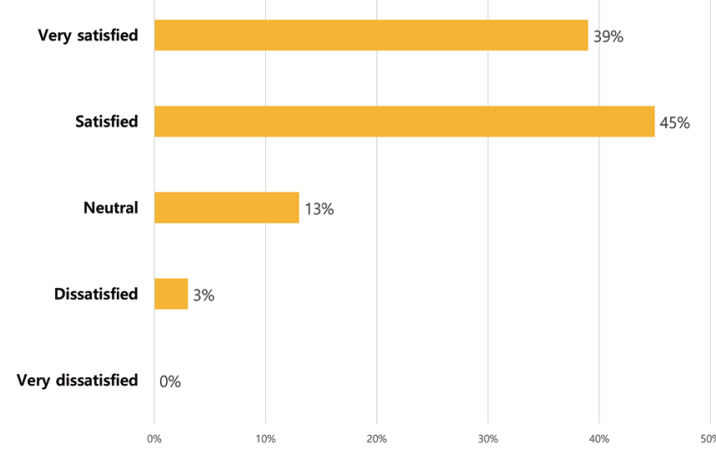

A

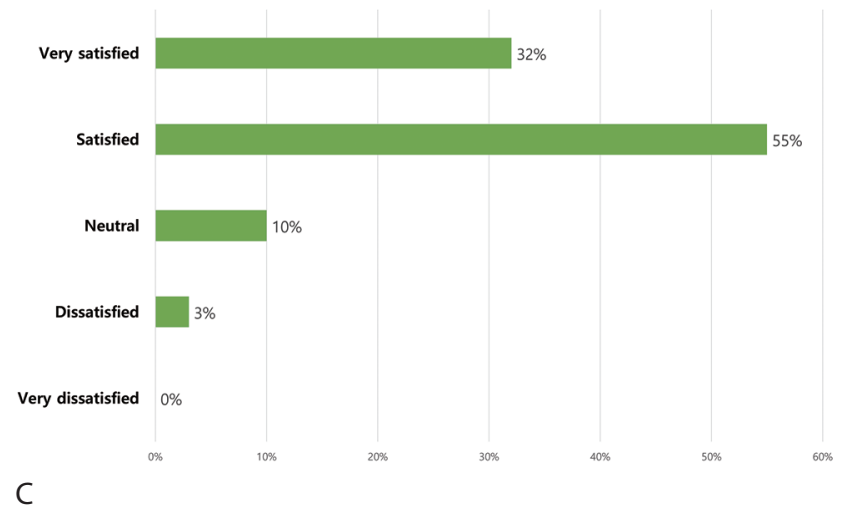

연기되며 온라인-오프라인 병행으로 변경된 점과 접속 방법에 대한 안내는 $92 \%$ 에서 전반적으로 양호했다고 하였다.

현장 참석자를 대상으로 한 설문 결과는 Fig. 3과 같다. 학회장에서의 방역 대책 및 준비에 대한 만족도는 매우 만족 $56 \%$, 만족 34\%로 나타났으며, 특별한 문제 제기는 없었다. 학회장에서 발표자의 $\mathrm{VOD}$ 강의에서 화질 및 음성 만족도는 매우 만족 $42 \%$, 만족 $37 \%$ 였으며, 보통 혹은 불만족스럽다는 의견이 $22 \%$ 로 나타났다. 온라인 참석자를 대상으로 한 설문

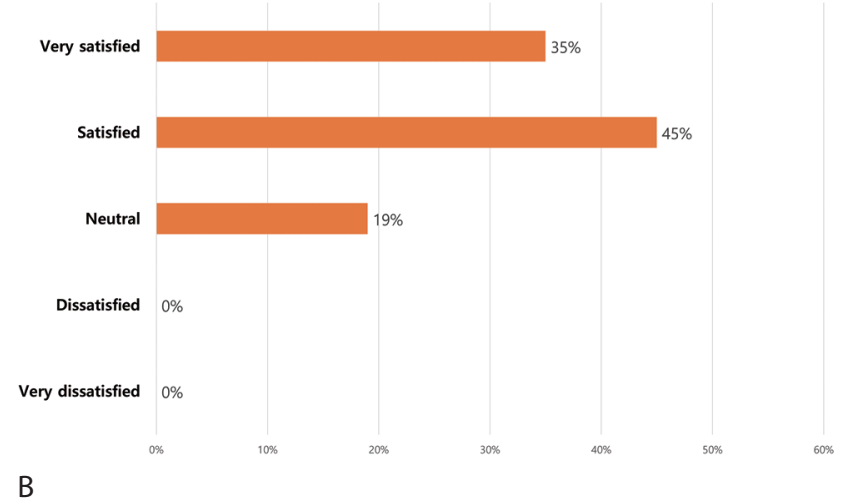

Fig. 4. Survey result from online-attendee in IC-KPBA 2020. (A) Satisfaction level about the online network. (B) Satisfaction level about the quality of video. (C) Satisfaction level about the quality of sound.

결과는 Fig. 4와 같다. 온라인 접속 및 네트워크 상태에 대해서는 매우 만족 $39 \%$, 만족 $45 \%$ 로 나타났으나 $3 \%$ 에서는 네트워크에서의 끊김 및 불만족을 호소하였다. 온라인 강의의 화질 및 영상에 대해서는 $80 \%$ 에서 만족스럽다고 답변하였으며 화질의 불만족은 없었다. 음성 및 사운드 관련한 사항에서는 학회장에서 발표자의 VOD 강의에서 화질 및 음성 만족도는 매우 만족 $32 \%$, 만족 $55 \%$, 보통 $10 \%$ 였으며 음성 관련 불만족은 $3 \%$ 로 집계되었다. 비대면 학술대회에 참석하였을 때 발표자가 


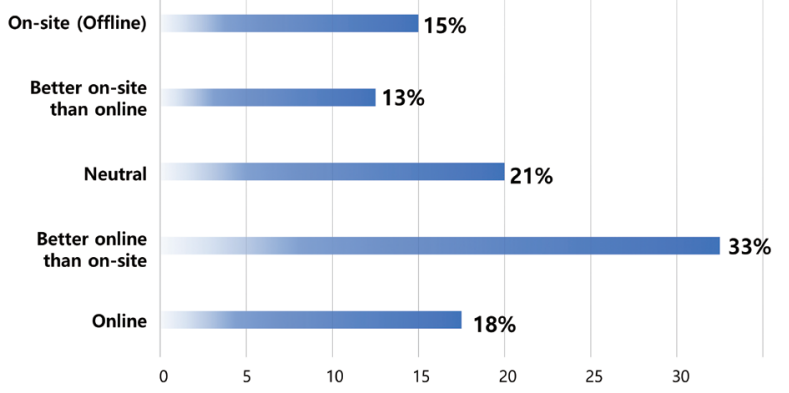

Fig. 5. Preferred plan to attend a future conference under COVID-19 pandemic.

온라인으로 강의를 진행할 때 선호도는 복수응답에서 원격 실시간 강의가 $41 \%$, 사전 녹화된 동영상 강의가 $41 \%$ 가 좋다고 대답하였으며 파워포인트 슬라이드를 이용한 녹음 강의는 $18 \%$ 로 상대적으로 낮은 만족도를 보였다.

본 설문조사의 답변에 대한 하위그룹 분석에서는 온라인과 오프라인의 그룹별 만족도 비교에서 만족 혹은 매우 만족으로 답변한 경우가 온라인 $91 \%$, 오프라인 $87 \%$ 로 온라인 참석자가 조금 더 높은 만족도를 보였다. 연령대 그룹별 만족도 비교에서는 만족 혹은 매우 만족스러웠다는 답변이 30 대 이하 $95 \%, 40$ 대 $88 \%, 50$ 대 이상 $83 \%$ 였으며, 상대적으로 답변자의 연령이 높을수록 비대면 학술대회에 대한 만족도가 낮은 경향을 보였다. 향후 COVID-19 유행 관련 문제가 지속될 경우 다음 학술대회에서 참석 방법에 대한 의견에서는 온라인을 선호한다는 의견이 $51 \%$, 상황에 따른 결정이 $21 \%$, 오프라인을 선호한다는 의견이 $28 \%$ 로 확인되었다(Fig. 5 ).

\section{고 찰}

2020년 COVID-19의 확산과 세계적 대유행으로 인해 우리 사회는 한 번도 경험해보지 못한 상황에 직면하게 되었다. 전염성 질환의 확산 방지를 위한 사회적 거리두기 캠페인은 기존에 당연하게 생각되던 회의나 모임을 비대면 방식으로 전환하게 하는 계기가 되었으며, 통신 기술의 발달과 원격 회의 기술의 발전, 개인용 통신기기의 보급 확대에 힘입어 비대면 기술은 사회 전반에 걸쳐 빠른 속도로 적용되기 시작하였다. 학계에서 정기적으로 시행되는 학술대회도 예외는 아니어서, 관련 분야의 연구 성과 발표와 최신 지견의 공유, 전문가 집단의 상호 교류가 중심이던 학술행사가 가상 공간에서의 온라인
학술대회나 온라인/오프라인 병행 학술행사로 전환되어 시행되는 것이 현재의 추세이다..$^{10-12}$ 하지만 이러한 흐름이 모든 구성원들에게 적절히 여겨지는 것은 아니다. 개인의 나이와 환경, 조건에 따라 차이가 있을 수 있으며, 비대면 기술 정보의 습득과 활용도에도 편차가 있을 수 있어 이러한 상황은 개인적 선호도에 따라 차이를 보인다. ${ }^{13,14}$ 본 설문조사 연구에서는 현재의 상황에서, 국내에서 대한췌장담도학회 주관 하에 개최된 IC-KPBA 2020 학술대회의 설문 조사 결과를 분석해 보았다.

COVID-19 유행에 직면하여, 비대면 교육이나 온라인 행사의 만족도와 인식에 대해서는 여러 가지 보고가 있다. ${ }^{15-20}$ 온라인 학술대회는 질문자가 대중에 노출없이 자유롭게 질문을 할 수 있고, 또한 청취자가 장소에 구애받지 않고 어디에서든 기기로 실시간 접속이 가능하다는 장점이 있다. 또한 기술적인 부분에 대한 점검부터 피드백의 수집, 개선점의 고찰 및 발전방안에 대해서도 많은 집단에서의 발전 방안이 다양하게 제시되고 있다. 하지만 의학계는 생명과 질환을 다룬다는 전문성과 각 분과의 개별적 특수성이 있어 타 학계와는 관점의 차이가 있을 수 있으며, 또한 각 분과에서도 전문 분야별 차이가 상당히 존재함을 고려해야 한다. 본 연구에서 분석한 IC-KPBA 2020 학술대회는 소화기내과에서 췌장담도 분야에 특화된 학술행사로, 참여자가 해당 분야의 전문가 집단으로 한정되어 있으며 관련 시술의 숙련자들이 주로 참석하기 때문에 직군이나 업무 환경에 따른 편차가 적다는 특징이 있다. 따라서 이 설문 결과는 조사 대상이 관련 전문분야의 이해도가 높은 숙련 의사들로 구성되었다는 점과 비대면 화상 기술을 통한 IC-KPBA 학회가 처음 시도되었던 점을 고려한다면, 향후 학회에서 계획 수립에 반영할 수 있는 중요한 정보로서 의미가 있다.

설문참여자의 연령 분포는 실제 참가자의 연령분포와 다소 차이가 있는데, 상대적으로 젊은 참석자가 온라인 설문조사 방식에 좀 더 적극적으로 응하였기 때문으로 생각된다. 온라인 참석자의 비율이 전체의 $41 \%$ 였다는 점은 처음 시도되는 방식에 대한 호응도가 예상보다 좋았다는 것을 의미하며, 데이터 사용에 대한 부담으로 대부분이 유선랜이나 와이파이 방식으로 접속하는 것을 선호하였다. 접속기기는 데스크탑 컴퓨터, 랩탑 컴퓨터나 타블렛이 주로 이용되었으며 화면의 크기가 작은 휴대용 통신기기는 학술행사의 도구로 선호도가 낮다는 점이 확인되었다. 학회장에서의 방역대책에 대한 만족도는 매우 높았으며, 학술 행사 후 유증상자 혹은 감염자에 
대한 보고가 전무하였던 점은 학회에서 수립한 현장의 방역 대책이 잘 작동하였던 것으로 평가될 수 있다.

온라인 접속과 네트워크 연결이 전반적으로 우수하였다는 평가는 대한민국의 전산망이 온라인 환경에 적절하다는 점을 시사하며, 특히 대용량의 데이터 연결이 요구되는 실시간 시술 시연에서도 네트워크 관련 문제점이 없었던 점은 기존의 미래네트워크 선도시험망(코렌, KOREN)에 의존하던 실시간 시술 시연이 각 병원의 전산 환경에서도 큰 문제없이 연결이 가능하다는 것을 의미한다. 이러한 결과는 내시경 분야 뿐만 아니라 수술 시연 등과 관련한 타 분야에서도 적용 가능하기에 적절한 플랫폼과 연결 방식에 대한 학회 간의 노하우 교환도 필요하다고 생각된다. 기존의 연구에서는 녹화 방송보다는 실시간 방송이 집중도가 높다는 점 그리고 발표자의 음성만 송출되는 것보다 발표자의 모습과 음성이 같이 포함될 경우 청취 효과가 높다는 결과가 있었다. 본 설문에서도 음성만 포함된 슬라이드 영상은 발표자의 모습이 포함된 실시간 혹은 녹화 영상보다 선호도가 상대적으로 낮았다. 따라서 향후 온라인 학회에서 발표자가 영상자료를 제작해서 제출해야 하는 경우, 조직위원회는 발표자에게 가급적 발표 모습을 영상에 포함하도록 권고하는 것이 참석자 및 청취자의 집중도를 향상에 도움이 되겠다. 화면의 질에 비해 음성의 질에서 불만족스럽다는 보고가 있었던 것은 비대면 환경에 대한 장비 구축에서 마이크나 스피커 장비의 준비가 다소 미흡하다는 점을 시사하므로 이에 대한 개선이 필요할 것으로 보인다.

IC-KPBA 2020 학술대회에서 공지는 각 구성원에게 일괄적으로 발송이 되었는데, 하위그룹간 분석에서는 연령대가 높아질수록 온라인 방식에 대한 만족도가 떨어지는 것으로 확인되었다. 이는 익숙하지 않은 환경의 영향도 있지만 접속 방식과 기기에 대한 접근도가 세대 간에 차이가 있는 점도 연관이 있다고 본다. 따라서, 학회에 대한 알림 공지 외에도 영상 및 음향 장치, 네트워크 구성 및 환경의 구축에도 적절한 정보가 제공된다면 참여자의 만족도 향상에 도움이 되리라 생각된다. 그리고 현재는 다양한 참여자의 실시간 토론이 다소 한계가 있는데, 향후 학술대회의 발전적인 향상을 위해서는 실시간 토론이 가능한 플랫폼 구축이 선결과제가 될 것이며, 또한 기존의 일대일 핸즈온 방식을 개선하여 가상 공간에서 시간과 장소에 구애받지 않는 교육 환경을 구축하는 것도 전문가를 양성하는 학회에서 필요한 과제가 되겠다.

본 설문조사가 내국인 참석자를 대상으로만 시행되었던 점은 아쉬운 점으로 남는다. 또한 학술대회 후 온라인으로 배포된
설문지의 회신율이 상대적으로 저조하였던 점도 온라인오프라인 병행 학술행사의 장단점을 평가하는 데에 한계로 작용하였다. 이러한 낮은 회신율은 학술대회 직후 국내 여건과 연관이 있는 것으로 보이는데, COVID-19 확산으로 인한 의료진의 업무 증가와 국내 의료 환경의 변화 등이 원활한 설문 회수에 방해 요소로 작용하였다고 생각된다. 하지만 COVID-19 라는 전대미문의 상황에서 의학계 전문 학술행사의 온라인 개최와 운영의 경험은 향후 학회의 발전 방안 수립에 큰 도움이 되었으며, 참여자의 피드백을 취합하여 분석한 본 연구는 향후 발전적인 학술대회를 계획하는 데 중요한 자료를 제공하였다는 데 의의가 있다.

빠르게 변화하는 현재의 상황에서 COVID-19의 추세와 사회적인 동향에 따른 대처는 매우 중요한 사항이다. 회원들의 의견을 충분히 반영한 장기 계획 수립 그리고 새로운 방식에 대한 도전은 학회와 구성원 모두의 발전을 도모할 수 있는 추진력이 될 것이라 생각하며, 나아가 의료분야 전반에서 학회의 역할과 위상을 향상시키는 좋은 계기가 될 것이다.

\section{요 약}

배경/목적: 본 연구는 증증급성호흡기증후군(COVID-19)의 확산에 따라 학술행사의 방식이 직접 참석에서 비대면 온라인 방식으로 점차 변화되는 현재의 경향을 고려하여, 2020년 시행된 학술행사 참석자들의 만족도를 분석한 연구이다. 설문조사를 통해 비대면 온라인 학술대회의 장점과 단점을 분석하고, 이를 토대로 향후 이상적인 학술대회를 준비할 수 있는 자료를 수립하고자 하였다.

방법: 2020년 상반기에 서울에서 개최된 'IC-KPBA 2020' 학술행사의 참석자를 대상으로 18 개 문항으로 구성된 설문조사를 시행하였다. 설문조사는 네이버 설문조사의 플랫폼을 이용하여 진행되었다.

결과: 비대면 온라인 방식의 학술행사에 대해서 학회 참석자들은 전반적으로 만족 혹은 매우 만족스럽다고 응답하였다. 온라인 참석자들은 네트워크 연결, 화면 및 음향 등의 각각의 항목에서 약 $70-85 \%$ 가 만족 혹은 매우 만족으로 응답하였으며, 직접 참석자들을 대상으로 한 설문에서 방역대책 및 현장의 화면, 음향 시설 등의 각각의 항목에서 약 80-90\%가 만족 혹은 매우 만족으로 응답하였다. 향후 학회 참석 방식의 선호도 조사에서는 가급적 온라인을 선택하겠다는 
답변이 $33 \%$ 로 가장 높게 나타났다.

결론: 학술행사의 방식이 점차 비대면 온라인으로 변화되는 추세에서 대한췌장담도학회 주관 하에 새로운 방식으로 개최한 국제학술대회에 대한 만족도는 전반적으로 양호-우수한 것으로 확인되었다.

국문 색인: 코로나바이러스감염증-19, 팬데믹, 학술대회, 피드백, 설문조사

\section{Conflicts of Interest}

The authors have no conflicts to disclose.

\section{REFERENCES}

1. World Health Organization (WHO). Coronavirus disease (COVID-19) weekly epidemiological update and weekly operational update [Internet]. Geneva: WHO [cited 2020 Sep 1]. Available from: https://www.who.int/ emergencies/diseases/novel-coronavirus-2019/situation-reports.

2. Cohen J, Normile D. New SARS-like virus in China triggers alarm. Science 2020;367:234-235.

3. Zhu $N$, Zhang $D$, Wang $W$, et al. A novel coronavirus from patients with pneumonia in China, 2019. N Engl J Med 2020;382:727-733.

4. van Doremalen N, Bushmaker T, Morris DH, et al. Aerosol and surface stability of SARS-CoV-2 as compared with SARS-CoV-1. N Engl J Med 2020;382:1564-1567.

5. Ong SWX, Tan YK, Chia PY, et al. Air, surface environmental, and personal protective equipment contamination by severe acute respiratory syndrome coronavirus 2 (SARS-CoV-2) From a Symptomatic Patient. JAMA 2020;323:1610-1612.

6. Houston S. Lessons of COVID-19: virtual conferences. J Exp Med 2020;217:e20201467.

7. Rubinger L, Gazendam A, Ekhtiari S, et al. Maximizing virtual meetings and conferences: a review of best practices. Int Orthop 2020;44:1461-1466.

8. Porpiglia F, Checcucci E, Autorino R, et al. Traditional and virtual con- gress meetings during the COVID-19 pandemic and the post-COVID-19 era: is it time to change the paradigm?. Eur Urol 2020;78:301-303.

9. Bottanelli F, Cadot B, Campelo F, et al. Science during lockdown from virtual seminars to sustainable online communities. J Cell Sci 2020;133:jcs249607.

10. Rush MJ, McPheron A, Martin SJ, Kier KL. Transitioning a regional residency conference from an in-person to a virtual format in response to COVID-19 travel restrictions. Am J Health Syst Pharm 2020;77:1826-1827.

11. Kopec KT, Stolbach A. Transitioning to virtual: ACMT's 2020 annual scientific meeting. J Med Toxicol 2020;16:353-355.

12. Pozniak A, Bekker LG, Kamarulzaman A, et al. A COVID-19 conference at AIDS 2020: virtual. Lancet 2020;395:1598-1599.

13. Gyurko R, Neste C, Dragan IF. Transitioning clinical rotations to a virtual experience: problem, solution, and results. J Dent Educ 2020 Jun 29. [Epub ahead of print]

14. Hodgson JC, Hagan P. Medical education adaptations during a pandemic: transitioning to virtual student support. Med Educ 2020;54:662-663.

15. Chen T, Peng L, Yin X, Rong J, Yang J, Cong G. Analysis of user satisfaction with online education platforms in China during the COVID-19 pandemic. Healthcare (Basel) 2020;8:200.

16. Trevino KM, Raghunathan N, Latte-Naor S, et al. Rapid deployment of virtual mind-body interventions during the COVID-19 outbreak: feasibility, acceptability, and implications for future care. Support Care Cancer 2021;29:543-546.

17. Park J, Park H, Lim JE, Rhim HC, Lee YM. Medical students' perspectives on recommencing clinical rotations during coronavirus disease 2019 at one institution in South Korea. Korean J Med Educ 2020;32:223-229.

18. Jiménez-Rodríguez D, Torres Navarro MDM, Plaza Del Pino FJ, Arrogante 0 . Simulated nursing video consultations: an innovative proposal during COVID-19 confinement. Clin Simul Nurs 2020;48:29-37.

19. Tenforde AS, Borgstrom H, Polich G, et al. Outpatient physical, occupational, and speech therapy synchronous telemedicine: a survey study of patient satisfaction with virtual visits during the COVID-19 pandemic. Am J Phys Med Rehabil 2020;99:977-981.

20. Durfee SM, Goldenson RP, Gill RR, Rincon SP, Flower E, Avery LL. Medical student education roadblock due to COVID-19: virtual radiology core clerkship to the rescue. Acad Radiol 2020;27:1461-1466. 
대한췌장담도학회 기획위원회

안녕하십니까?

대한췌장담도학회에서는 COVID-19에 대하여 IC-KPBA 2020 학술대회를 온/오프라인 병행으로 시행한 바 있습니다. 이에 대한 만족도 현황을 조사하여 학술대회의 개선 및 발전을 도모하고자 하오니, 바쁘시더라도 조사에 응해주시면 우리나라 ERCP의 질 향상에 크게 도움이 될 것으로 생각합니다.

감사합니다

1. 선생님의 연령을 기입해주세요.

2. 선생님의 성별은 어떻게 되십니까? ( )
1)남
2)여

3. 선생님께서 근무하시는 병원의 형태는 무엇입니까? ( )
1) 상급종합병원
2) 종합병원
3) 병원급
4) 의원 및 기타

4. 선생님께서 근무하시는 지역은 어디입니까? ( )
1) 서울특별시
2) 경기도 혹은 인천광역시
3) 경상남도 혹은 부산광역시
4) 경상북도 혹은 대구광역시, 울산광역시
5) 전라남도 혹은 광주광역시
6) 전라북도
7) 충청남도 혹은 대전광역시
8) 충청북도
9) 강원도
10) 제주특별자치도

5. 선생님께서 소속된 의료기관의 오프라인 학회 참석 제한은 현재 어느 정도입니까? ( )
1) 제한 없음
2) 신청 후 참석 가능 (허가 불필요)
2) 신청 후 소속기관 승인 시 참석 가능 (허가 필요)

3) 필수 참석자만 선택적으로 승인 (좌장, 연자만 허가; 일반 참석자는 불허)

4) 예외 없이 금지 (온라인만 가능)

6. IC-KBPA 2020에 참석하신 방법은 어느 것입니까? ( )
1) 오프라인 (직접 참석)
2) 온라인

7. IC-KBPA 2020에 대한 온라인/오프라인 참여 방법에 대한 학회의 사전 공지에 대한 만족도는 어느 정도입니까?
1) 매우 만족
2) 만족
3) 보통
4) 불만족
5) 매우 불만족

8. (오프라인 참석자 대상) IC-KBPA 2020의 학회장에서 방역 대책 및 준비에 대한 만족도는 어느 정도입니까?
1) 매우 만족
2) 만족
3) 보통
4) 불만족
5) 매우 불만족
6) 해당사항 없음 (온라인 참석)

9. (오프라인 참석자 대상) IC-KBPA 2020에서 $\mathrm{VOD}$ 강의에서 화질 및 음성 관련된 만족도는 어느 정도입니까?
1) 매우 만족
2) 만족 

3) 보통
4) 불만족
5) 매우 불만족
6) 해당사항 없음 (온라인 참석)

10. (온라인 참석자 대상) 선생님께서 IC-KBPA 2020에 온라인 접속한 기기는 어느 것입니까?
1) 데스크탑 PC
2) 노트북 혹은 타블렛 PC
3) 안드로이드폰 혹은 아이폰
4) 기타
5) 해당사항 없음 (오프라인 참석)

11. (온라인 참석자 대상) 선생님께서 IC-KBPA 2020의 접속 방식은 어느 것입니까?
1) 유선랜
2) 와이파이
3) 무선데이터
4) 해당사항 없음 (오프라인 참석)

12. (온라인 참석자 대상) IC-KBPA 2020에서 온라인 접속 및 네트워크 상태에 대한 만족도는 어느 정도입니까?
1) 매우 만족
2) 만족
3) 보통
4) 불만족
5) 매우 불만족
6) 해당사항 없음 (오프라인 참석)

12. (온라인 참석자 대상) IC-KBPA 2020에서 온라인상 강의에서 화질 및 영상과 관련된 만족도는 어느 정도입니까?
1) 매우 만족
2) 만족
3) 보통
4) 불만족
5) 매우 불만족

6) 해당사항 없음 (오프라인 참석)

13. (온라인 참석자 대상) IC-KBPA 2020에서 온라인상 강의 에서 음성 및 사운드 관련된 만족도는 어느 정도입니까?
1) 매우 만족
2) 만족
3) 보통
4) 불만족
5) 매우 불만족
6) 해당사항 없음 (오프라인 참석)

14. 선생님께서는 학술대회에서 강의자가 온라인으로 강의를 진행할 때 어느 방식이 좋으십니까? (복수 선택)
1) 원격 실시간 강의 (Zoom, MS 팀즈, 시스코 Webex 등)
2) 사전 녹화된 동영상 강의
3) 사전 녹음된 Power point 강의
4) 기타

15. 비실시간 강의 시 질문은 App이나 E-mail로 하시도록 요청 드렸습니다. 질문을 하신 경우 답변 확인이 가능하셨습니까 (회신일 기준)?
1) 예
2) 아니오
3) 해당사항 없음

16. 현재의 COVID-19 관련 이슈가 지속 시, 차기 대한췌장담도 학회의 학술대회에서 선생님의 참석 방법은 어느 방법을 고려 중이십니까?
1) 오프라인 (부득이한 상황을 제외하면)
2) 가급적 오프라인을 선택
3) 상황에 따라 결정
4) 가급적 온라인을 선택
5) 온라인 (부득이한 상황을 제외하면)

17. 이번 IC-KBPA 2020에서 개선 사항을 자유롭게 기술해 주세요 